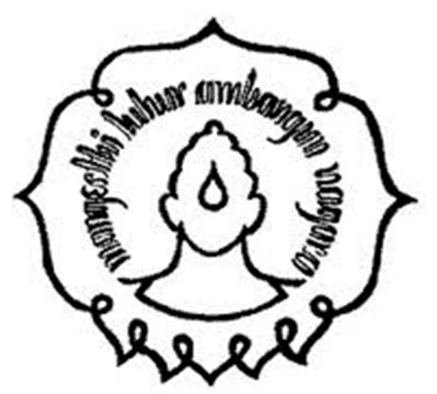

JURNAL

Oleh :

SUGIANTO

K1512061

FAKULTAS KEGURUAN DAN ILMU PENDIDIKAN UNIVERSITAS SEBELAS MARET

SURAKARTA

OKTOBER 2017 


\title{
STUDI EKSPERIMEN PENAMBAHAN CAMPURAN ABU AMPAS TEBU DAN SERAT BAMBU PADA KUAT LEKAT BETON
}

\author{
Sugianto $^{1}$, Anis Rahmawati ${ }^{2}$, Ida Nugroho ${ }^{3}$ \\ Pendidikan Teknik Bangunan, Universitas Sebelas Maret \\ e-mail: sugiyantoptb@gmail.com
}

\begin{abstract}
Abstrak:Tujuan penelitian ini adalah 1)Mengetahui pengaruh penggantian sebagian agregat halus menggunakan abu ampas tebu dengan variasi $0 \%, 5 \%$, $10 \%, 15 \%$ dan serat bambu $0 \%, 1,5 \%$ dan 3\% terhadap kuat lekat beton, 2) Mengetahui persentase optimal penggantian sebagian agregat halus menggunakan abu ampas tebu dan serat bambu yang menghasilkan kuat lekat maksimal pada beton. Penelitian menggunakan metode kuantitatif eksperimen dan teknik analisa data menggunakan regresi. Variabel dalam penelitian ini adalah (1)Variabel bebas yang berupa variasi penggantian sebagian agregat halus menggunakan abu ampas tebu dan variasi penambahan serat bambu, (2)Variabel terikat diantaranya Kuat Lekat dan Porositas beton. Hasil penelitian ini adalah 1)Penggantian sebagian agregat halus menggunakan abu ampas tebu berpengaruh negatif terhadap kuat lekat beton serat dan penambahan serat bambu bersifat positif terhadap kuat lekat beton serat, 2) Nilai optimal penggantian sebagian agregat halus menggunakan Abu Ampas Tebu dan penambahan serat bambu yang menghasilkan kuat lekat maksimal sebesar 63,04 $\mathrm{MPa}$ pada persentase abu ampas tebu $0 \%$ dan serat bambu $3 \%$.
\end{abstract}

Kata Kunci: abu ampas tebu, serat bambu, beton serat 


\author{
ABSTRACT \\ EXPERIMENTAL STUDY OF ADDITIONAL SUGARCANE BAGASSE \\ ASH (SCBA) AND BAMBOO FIBER ON BOND STRENGTH \\ CONCRETE \\ Sugianto $^{1}$, Anis Rahmawati ${ }^{2}$, Ida Nugroho ${ }^{3}$ \\ Pendidikan Teknik Bangunan, Universitas Sebelas Maret \\ e-mail: sugiyantoptb@gmail.com
}

\begin{abstract}
The purpose of this research were 1) determine the effect of partial replacement of fine aggregate use to bagasse ash addition with variation $0 \%, 5 \%$, $10 \%, 15 \%$ and $0 \%, 1.5 \%$ and $3 \%$ of bamboo fiber on strength of concrete, 2 ) determine an optimum percentage partial replacement of fine aggregate use to bagasse ash and bamboo fiber addition which produced a maximum bond strength of concrete. The research used quantitative experimental method and analysis data using regression. Variable in this research were (1) The independent variables are variations addition of partial replacement of fine aggregate use to bagasse ash and the variations of bamboo fiber addition. (2) The dependent variable are bond strength and porosity of concrete. The results of the research were, 1) Partial replacement of fine aggregate use to bagasse ash take negative effect to the bond strength of fiber concrete and the addition of bamboo fiber take positive effect to the bond strength of fiber concrete, 2) There was an optimum Partial replacement of fine aggregate use to bagasse ash and bamboo fiber addition that produced a maximum bond strength of $63,04 \mathrm{MPa}$ at percentage $0 \%$ of bagasse ash and $3 \%$ of bamboo fiber.
\end{abstract}

Keywords: bagasse ash, bamboo fiber, fiber concrete. 


\section{PENDAHULUAN}

Konsep teknologi ramah lingkungan telah menginspirasi para peneliti untuk berbuat lebih banyak dalam melindungi lingkungan hidup. Menurut penelitian A.Baharudeen (2015, 77-88) Pemanfaatan limbah sebagai bahan bangunan alternatif telah menjadi cara yang populer untuk mengatasi masalah lingkungan disebagian besar negara berkembang karena limbah abu ampas tebu langsung dibuang pada daratan atau tanah yang ada disekitar tempat pengolahan tebu. Abu ampas tebu adalah salah satu limbah yang berpotensi untuk digunakan sebagai bahan campuran dalam material bangunan.

Indonesia sebagai negara agraris memiliki banyak kekayaan alam dari sektor perkebunan. Berbagai jenis perkebunan yang dapat menjadi komoditi export dapat ditemukan di Indonesia seperti perkebunan tebu, tembakau, karet, kelapa sawit, perkebunan buah-buahan dan lainya. Diantara semua jenis perkebunan di Indonesia tersebut, perkebuanan tebu merupakan perkebunan yang banyak ditemui di daerah solo raya. Abu ampas tebu (AAT) adalah sisa hasil pembakaran dari ampas tebu. ampas tebu sendiri merupakan

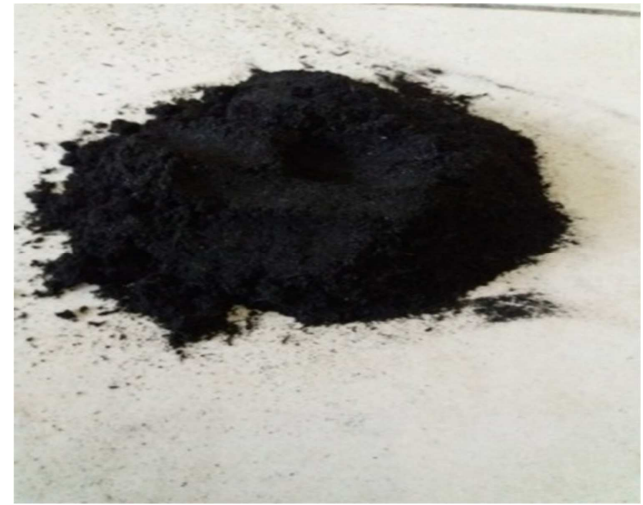

Gambar 1 Abu Ampas Tebu

hasil limbah buangan yang berlimpah dari proses pembuatan gula. Pembakaran ampas tebu memiliki unsur yang bermanfaat untuk peningkatan kekuatan beton, karena menurut A.Baharudeen (2015,77-88) abu ampas tebu mempunyai sifat pozzolan dan mengandung silica yang menonjol. Bila unsur ini dicampur dengan semen akan menghasilkan kekuatan yang lebih tinggi. Dari penelitian sebelumnya oleh Gerry Phillip Rompas (2013, 82-89) didapatkan bahwa hasil pengujian oleh balai Riset dan Standarisasi Industri Manado diperoleh kandungan silica abu ampas tebu sebesar 68,5\% sehingga memiliki sifat pozzolan. Hali ini disampaikan juga oleh prashant (2013, 25-29) yang melakukan penelitian dengan menggunakan abu ampas tebu dalam

rasio $0 \%, 10 \%, 20 \%, 30 \%$ dan $40 \%$ dari volume agregat halus, [diperoleh hasil bahwa] penggantian AAT sebesar $10 \%$ dari volume agregat halus secara efektif meningkatkan kekuatan pada beton. Penelitian ini 
mengaplikasikan pemanfaatan limbah abu ampas tebu sebagai bahan alternatif yang dapat menggantikan agregat halus. Selain itu, pada campuran beton akan ditambahkan juga serat bambu sebagai material perkuatan beton. Bambu merupakan tanaman ordo Bambooidae yang pertumbuhannya cepat dan dapat dipanen pada umur sekitar 3 tahun.

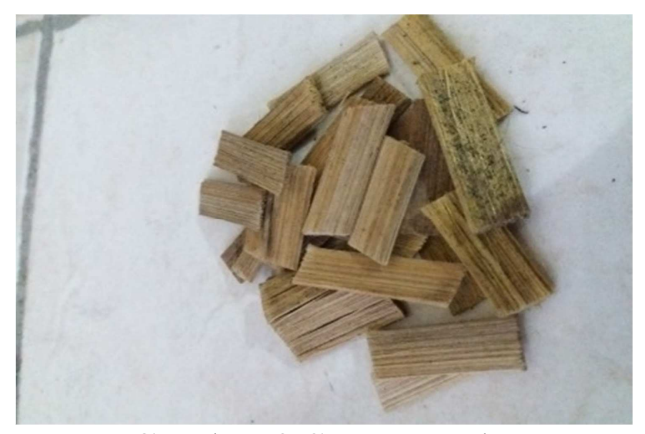

Gambar 2 Serat Bambu

Pada masa pertumbuhan, bambu dapat tumbuh vertikal $5 \mathrm{~cm}$ per jam atau $120 \mathrm{~cm}$ per hari (Morisco,1996). Mencampurkan serat bambu legi pada beton dengan variasi $0 \%, \quad 1,5 \%$ dan $3 \%$ dari berat semen dapat mempengaruhi kekuatan beton (Mudji, 1999, 8890). Dengan kenaikan terbesar terjadi pada variasi $1,5 \%$. Fokus pada penelitian ini adalah memanfaatkan bahan limbah yaitu abu ampas tebu sebagai pengganti agregat halus serta menambahkan serat bambu pada beton untuk [meningkatkan nilai guna bahan limbah sekaligus memperbaiki sifat mekanik beton. Tujuan yang hendak dicapai dalam penelitian ini adalah untuk mengetahui pengaruh penambahan AAT dan serat bambu terhadap kuat tekan [beton]. Kajian pustaka Abu ampas tebu termasuk bahan pozzolan. Pozzolan adalah bahan yang mengandung senyawa silica dan alumina, yang tidak mempunya sifat semen, akan tetapi dalam bentuk halusnya dan dengan adanya air dapat menjadi suatu massa padat yang tidak larut dalam air. (Tjokrodimuljo, 1996:V.4).

Pozzolan dapat dibagi menjadi 2 bagian, yaitu:

1. Pozzolan alam: yaitu bahan alam yang merupakan sedimentasi dari abu atau larva gunung yang mengandung silica aktif, yang bila dicampur dengan kapur padam akan mengadakan proses sementasi

2. Pozzolan buatan: jenis ini banyak macamnya baik merupakan sisa pembakaran dari tungku, maupun pemanfaatan limbah yang diolah menjadi abu yang mengandung silika reaktif dengan proses pembakaran. Pozzolan dapat ditambahkan pada campuran adukan beton dan mortar (sampai pada batas tertentu dapat menggantikan semen), untuk memperbaiki kelecakan, membuat beton lebih kedap air (mengurangi permeabilitas dan yang sifat agresif. Abu ampas tebu adalah sisa dari pembakaran ampas tebu. Ampas tebu itu sendiri merupakan hasil limbah buangan yang berlimpah dari proses pembuatan gula $( \pm 30 \%$ dari kapasitas giling). Komposisi kimia abu ampas tebu dapat dilihat pada kandungan senyawa AAT

$1 \mathrm{SiO} 248$ - 81

$2 \mathrm{Al} 2 \mathrm{O} 31-19$

$3 \mathrm{Fe} 2 \mathrm{O} 32-12$

$4 \mathrm{CaO} 2-4$

$5 \mathrm{~K} 2 \mathrm{O} \quad 0,2-1,8$

$6 \mathrm{MgO} 1-4$ 
$7 \quad \mathrm{Na} 2 \mathrm{O} \quad 0,2-4$

8 P2O3 0,5 - 4

(Menurut Balai Riset \& Teknologi Sumaatera Barat: 2010)

Dari data ini dapat dilihat bahwa kandungan atau komposisi senyawa kimia yang dominan adalah $\mathrm{SiO} 2$ (silica) sebesar 46-81\%. Komposisi tersebut menguntungkan abu ampas tebu bila bahan ini digunakan sebagai bahan pengisi dalam campuran beton Berdasarkan SNI 03-2834-2000, bahan tambah adalah bahan yang ditambahkan pada campuran bahan pembuatan beton untuk tujuan tertentu. Admixture adalah bahan-bahan yang ditambahkan kedalam campuran beton pada saat atau selama pencampuran berlangsung. Fungsi dari bahan ini adalah untuk mengubah sifat-sifat dari beton agar menjadi lebih cocok untuk pekerjaan tertentu, atau untuk menghemat biaya.

Menurut Tjokrodimulyo (2004: V.4), "Beton serat adalah bahan komposit yang terdiri dari beton biasa dan bahan lain yang berupa serat. Serat pada umumnya berupa batang-batang dengan diameter antara 5 dan 500 mikro meter dan panjang sekitar $25 \mathrm{~mm}$ sampai 100 mm. bahkan serat dapat berupa : serat asbestos, serat tumbuhtumbuhan (rami, bambu, ijuk), serat plastik (polypropylene) atau potongan kawat baja". Penggunaan bambu sebagai bahan serat beton didasarkan pada pertimbangan bahwa kuat tariknya cukup tinggi, pembuatan dari bahan baku menjadi serat cukup mudah dan tidak perlu peralatan khusus. Serta populasi bambu yang cukup banyak dan tersebar sehingga mudah diperoleh. Bambu Legi sebagai salah satu jenis bambu di Indonesia, meskipun jarang dibudidayakan secara khusus, namun banyak tumbuh di lahan lahan liar seperti di tepi sungai, tebing-tebing dan sebagainya. Bambu jenis tersebut juga jarang dimanfaatkan sebagai bahan pokok bangunan, sehingga harga pasaran relative murah dibandingkan bambu jenis lain.

\section{METODOLOGI PENELITIAN}

Metode yang digunakan dalam penelitian ini adalah metode kuantitatif dengan desain penelitian eksperimental yang dilakukan di laboratorium untuk memberikan suatu gambaran mengenai pengaruh penggunaan abu ampas tebu dan serat bambu tehadap kuat lekat. Persentase penambahan abu ampas tebu tehadap volume agregat halus yaitu $0 \%, 5 \%, 10 \%$, dan $15 \%$. Sedangkan Persentase penambahan serat bambu terhadap berat semen yaitu $0 \%$, 1,5\%, dan 3\%. Sampel yang digunakan berupa beton berbentuk silinder dengan diameter $150 \mathrm{~mm}$ dan tinggi $300 \mathrm{~mm}$ sebanyak 48 buah. Dapat di lihat pada tabel

Tabel 1 Sampel Benda Uji

\begin{tabular}{|c|c|c|c|c|}
\hline No & AAT & $\begin{array}{l}\text { Serat } \\
\text { Bambu }\end{array}$ & $\begin{array}{l}\text { Benda } \\
\text { Uji }\end{array}$ & Jumlah \\
\hline \multirow[b]{3}{*}{1} & \multirow[b]{3}{*}{$0 \%$} & $1,5 \%$ & & \\
\hline & & $2 \%$ & & \\
\hline & & $0 \%$ & 4 & 12 \\
\hline \multirow[b]{2}{*}{2} & \multirow[b]{2}{*}{$5 \%$} & $1,5 \%$ & & \\
\hline & & $2 \%$ & 4 & 12 \\
\hline
\end{tabular}




\begin{tabular}{|c|c|c|c|c|}
\hline & & $0 \%$ & & \\
\hline \multirow[b]{3}{*}{3} & \multirow[b]{3}{*}{$10 \%$} & $1,5 \%$ & \multirow[b]{3}{*}{4} & \multirow[b]{3}{*}{12} \\
\hline & & $2 \%$ & & \\
\hline & & $0 \%$ & & \\
\hline \multirow[b]{3}{*}{4} & \multirow[b]{3}{*}{$15 \%$} & $1,5 \%$ & & \\
\hline & & $2 \%$ & & \\
\hline & & $0 \%$ & 4 & 12 \\
\hline \multicolumn{3}{|c|}{ Total Benda Uji } & & 48 \\
\hline
\end{tabular}

Total Sample 48

Tabel 2 Hasil Pengujian Agregat Halus

Alat dan bahan:

\begin{tabular}{|c|c|c|c|c|}
\hline \multicolumn{4}{|c|}{ Hasil Pengujian Agregat Halus } & \multirow[t]{2}{*}{ Gambar 3 Pasir } \\
\hline Parameter & Hasil & Standar & Keterangan & \\
\hline $\begin{array}{l}\text { Kadar } \\
\text { lumpur }\end{array}$ & $0,15 \%$ & $<5 \%$ & $\begin{array}{l}\text { Memenuhi } \\
\text { standar }\end{array}$ & $\begin{array}{l}\text { Butiran-butiran mineral keras } \\
\text { dan tajam berukuran antara } 0,075\end{array}$ \\
\hline $\begin{array}{l}\text { Kadar zat } \\
\text { organik }\end{array}$ & $0-10$ & - & Penurunan & $-5 \mathrm{~m}$ \\
\hline Kadar air & $1,97 \%$ & $1-3 \%$ & $\begin{array}{l}\text { kekuatan } \\
\text { Memenuhi } \\
\text { standart }\end{array}$ & \\
\hline $\begin{array}{l}\text { Bulk Specific } \\
\text { Gravity SSD }\end{array}$ & 2,63 & $2,5-2,7$ & $\begin{array}{l}\text { Termasuk } \\
\text { agregat } \\
\text { halus } \\
\text { normal }\end{array}$ & \\
\hline $\begin{array}{l}\text { Modulus } \\
\text { kehalusan }\end{array}$ & 3,91 & $1,5-3,8$ & $\begin{array}{l}\text { Tidak } \\
\text { Memenuhi } \\
\text { standart }\end{array}$ & \\
\hline Gradasi & $\begin{array}{l}\text { Daerah } \\
\text { I }\end{array}$ & & $\begin{array}{l}\text { Dapat } \\
\text { digunakan }\end{array}$ & \\
\hline \multicolumn{5}{|l|}{ Alat } \\
\hline $\begin{array}{ll}\text { 1. } & \text { Mole } \\
\text { 2. } & \text { Mold } \\
\text { 3. } & \text { UTM } \\
& \text { Mac }\end{array}$ & ing & rsal & ting & Hasil Pengujian Agregat Halus \\
\hline $\begin{array}{l}\text { Bahan } \\
\text { 1. Pasir }\end{array}$ & & & & \\
\hline
\end{tabular}

Gambar 3 Pasir

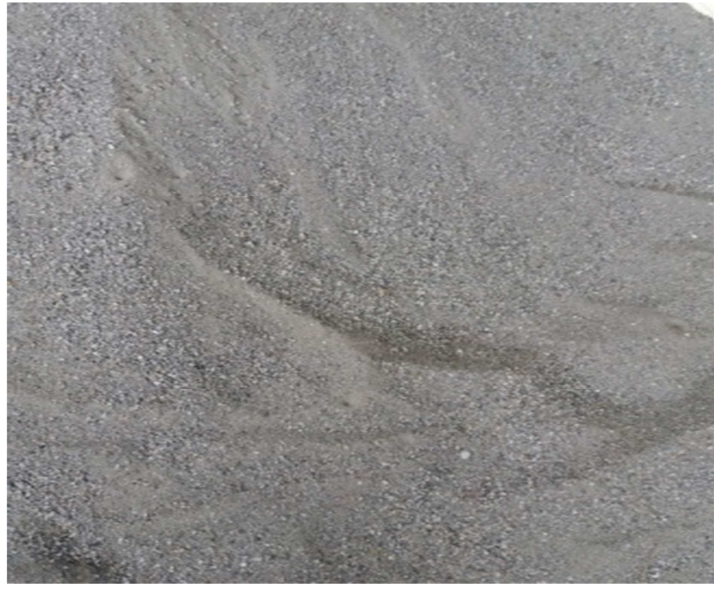




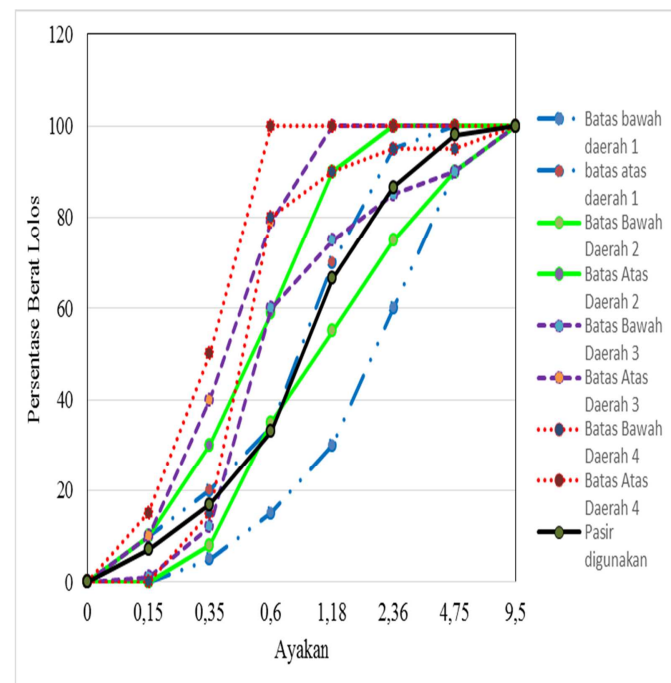

Gambar 4 Gradasi Agregat Halus

\section{Kerikil}

Kerikil, untuk butiran antara 5 $\mathrm{mm}$ dan $20 \mathrm{~mm}$.

Tabel 1.3 Hasil Pengujian Agregat Kasar

\begin{tabular}{llll}
\hline \multicolumn{3}{c}{ Hasil Pengujian Agregat Kasar } \\
\hline Parameter & Hasil & Standar & Keterangan \\
\hline Abrasi & $20,84 \%$ & $<50 \%$ & $\begin{array}{l}\text { Memenuhi } \\
\text { standar }\end{array}$ \\
$\begin{array}{l}\text { Bulk Specific } \\
\text { Gravity SSD }\end{array}$ & 2,416 & $2,5-2,7$ & $\begin{array}{l}\text { Termasuk } \\
\text { agregat } \\
\text { kasar tidak } \\
\text { normal }\end{array}$ \\
Modulus & 5,67 & $6-7,1$ & $\begin{array}{l}\text { Termasuk } \\
\text { agregat } \\
\text { Kehalusan } \\
\text { Butir kerikil tidak } \\
\text { Termasuk }\end{array}$ \\
& Daerah II & & normal \\
\hline
\end{tabular}

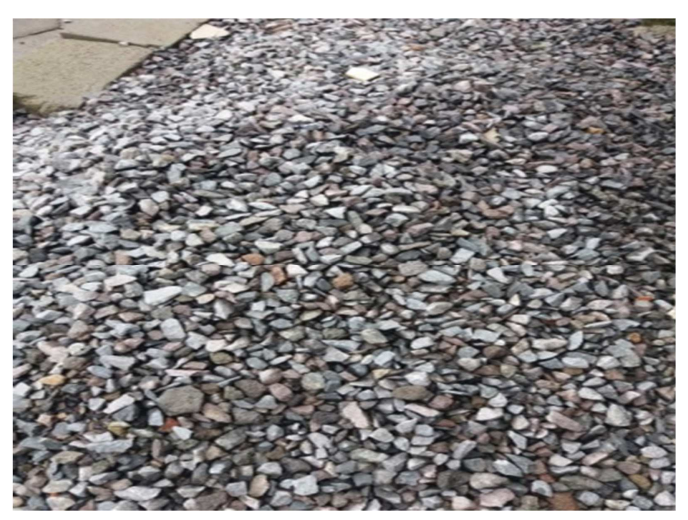

Gambar 5 Kerikil

Hasil Pengujian Agregat Kasar

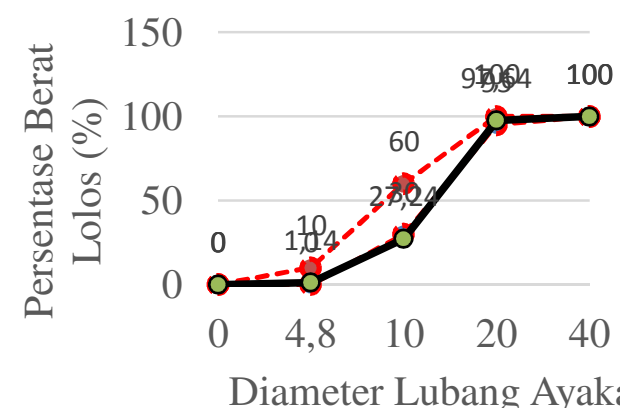

Gambar 6 Diameter Lubang Ayakan

3. Semen

Semen adalah zat yang digunakan untuk merekat batu, bata, batako, maupun bahan bangunan lainnya. 


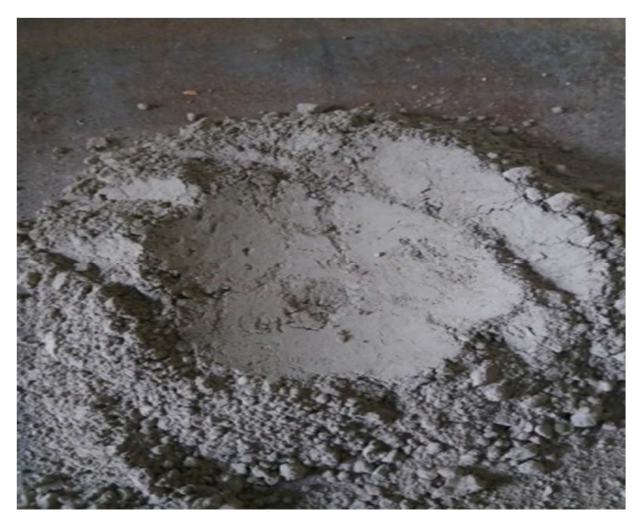

Gambar 7 Semen

4. Abu Ampas Tebu (AAT)

Ampas tebu adalah limbah yang dihasilkan dari proses penggilingan tebu setelah diambil niranya. Dari pengujian AAT yang telah dilaksanakan, diperoleh nilai kadar air $39.43 \%$ specific gravity SSD 1,33. Nilai modulus kehalusan 3.20 telah memenuhi syarat sebagai bahan pengganti agregat halus dengan modulus kehalusan antara 1,5-3,8.

4. Serat bambu

Serat bambu adalah bahan dasar bambu yang diolah hingga tipis.Serat bambu yang digunakan ukuran $20 \mathrm{~mm}$ x $10 \mathrm{~mm}$ x $5 \mathrm{~mm}$.

\section{HASIL PENELITIAN DAN PEMBAHASAN}

\section{Kuat Lekat}

Hasil pengujian kuat lekat rata-rata beton serat ditampilkan pada

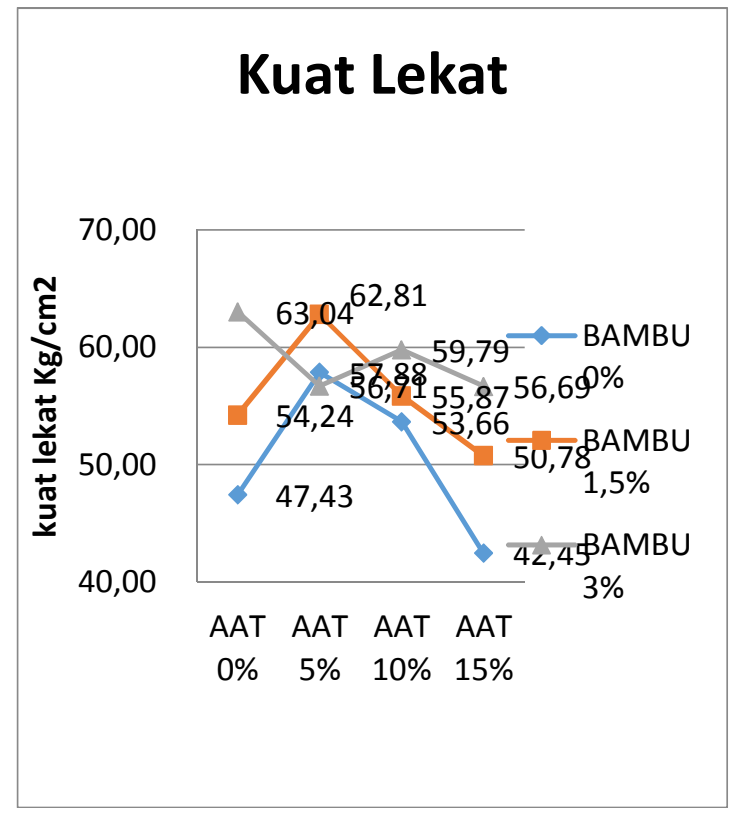

Gambar 8 Grafik Kuat Lekat

Penggunaan AAT $0 \%$ sampai $5 \%$ cenderung mengalami kenaikan kuat lekat beton serat tetapi pada variasi $5 \%$ sampai $15 \%$ pada beton mengalami penurunan kuat lekat. Penurunan terjadi dikarenakan penambahan persentasi AAT ditambah. AAT memiliki butiran yang sangat halus. Hal tersebut menyebabkan terjadinya lemahnya ikatan tulangan baja polos dan beton, hal tersebut juga menyebabkan beton memiliki rongga pada area tulangan benda uji. Oleh karena itu ikatan antar tulangan baja polos dan campuran beton serat melemah.

Hasil pengujian diatas menunjukkan penurunan kuat lekat. Penurunan kuat lekat terdapat dicampuran beton serat variasi AAT 5\% dan serat bambu 3\%. Penurunan ini terjadi dikarenakan faktor air semen atau (fas). Fas disini berfungsi untuk hidrasi semen, tetapi fas terserap oleh serat 
bambu dan AAT. Oleh karna itu menyebabkan lemahnya ikatan tulangan polos dan beton serat.

Kuat lekat beton dan baja tulangan tergantung pada faktorfaktor utama yaitu adanya adhesi antara elemen beton dan bahan penguatnya. Berdasarkan penelitian T.Subramani (2015) abu ampas tebu memiliki butiran-butiran yang sangat halus, dimana hal ini mempengaruhi kebutuhan air dalam campuran beton meningkat. Pada penelitian beton serat bambu dan AAT ini, pada proses pencampuran agregat kebutuhan air yang di perlukan untuk pencampuran agregat mengalami penambahan hal ini terlihat dari pengujian slump. Sejalan dengan pendapat Edward G. Nawy (1990: 398) bahwa kuat lekat beton dan baja tulangan tergantung pada faktor-faktor utama yaitu adanya adhesi antara elemen beton dan bahan penguatnya, efek memegang (griping) sebagai akibat dari susut pengeringan beton sekeliling tulangan dan saling geser antara tulangan beton dengan sekelilingnya, faktor diameter, bentuk dan jarak tulangan mempengaruhi retakan, tahan gesekan (friction) terhadap gelinciran dan saling mengait dengan tulangan mengalami gaya tarik.

Berdasarkan penelitian S.S Mousavi (2016) kuat lekat beton dengan penambahan campuran bubuk kapur memiliki ikatan tulangan baja dan beton memiliki kekuatan ikatan $10-40 \%$, hasil uji ini lebih besar dibanding ikatan beton normal tanpa campuran bubuk kapur. Sedangkan dalam penelitian beton serat ini didapatkan kekuatan ikatan 10$15 \%$, hasil uji ini lebih besar dibanding ikatan beton normal tanpa campuran AAT dan serat bambu. Sejalan dengan penelitian Zahra Dahou (2016) kekuatan ikatan tulangan baja dan beton atau kekuatan lekat dipengaruhi oleh tiga komponen terpisah yaitu adesi kimia, gesekan mekanik, dan bahan penyusun beton tersebut.

Menurut Ali Ergun (2016) kekuatan ikatan antara tulangan dan beton tergantung pada agregat penyusunan beton tersebut pada bahan campuran. Pada penelitian ini sebagian agregat halus digantikan menggunakan AAT. Hasil yang diperoleh menunjukkan penggunaan AAT sampai dengan $10 \%$ menunjukkan kuat lekat yang lebih tinggi dari beton normal.

Berdasarkan penelitian Anisa (2016) penambahan serat banner berpengaruh rendah terhadap kuat lekat beton. Pengaruh yang dihasilkan terhadap penambahan serat banner dengan hasil tertinggi pada penambahan persentase $0,40 \%$, yaitu 51,09 $\mathrm{kg} / \mathrm{cm}^{2}$. Penambahan serat banner dapat digunakan sebagai bahan tambah beton serat dengan penambahan tidak lebih dari $0,60 \%$ dimana kuat lekat beton serat masih berada diatas beton normal.

Peningkatan penyerapan energi terjadi hanya pada batasan 0 - $0,7 \%$ fraksi volume, apabila kandungan serat dinaikkan lagi hingga lebih besar dari 0,7 \%, maka kenaikan energi yang terjadi tidak terlalu besar. Beton bermutu tinggi lebih getas (brittle) dibandingkan 
dengan beton normal, dengan penambahan serat dapat dihasilkan beton yang lebih kuat berdasarkan Widodo (2014: 17) tentang beton serat. Menurut Sunarmasto (2007: 6) kuat lekat rata-rata beton normal pada umumnya pada tulangan polos adalah 3,279 $\mathrm{MPa}$ atau 32,79 $\mathrm{kg} / \mathrm{cm}^{2}$ sedangkan pada penelitian Karimah (2012: 196) kuat lekat rata-rata beton normal sebesar 3,02 $\mathrm{MPa}$ atau $30,2 \mathrm{~kg} / \mathrm{cm}^{2}$. Pada penelitian ini diperoleh kuat lekat maksimal 63,04\% dengan penambahan serat bambu 3\%.

\section{SIMPULAN， IMPLIKASI DAN SARAN \\ A. Simpulan}

Berdasarkan Hasil penelitian dan pembahasan tentang pengaruh penggunaan abu ampas tebu sebagai pengganti sebagian agregat halus serta penambahan serat bambu pada beton terhadap kuat lekat dan porositas beton serat, maka dapat disimpulkan bahwa:

1. Peggunaan AAT berpengaruh negatif, artinya bahwa semakin banyak penambahan AAT maka kuat lekat yang dihasilkan akan semakin menurun. Sedangkan penambahan serat bambu berpengaruh positif, artinya bahwa semakin banyak penambahan serat bambu maka kuat lekat yang dihasilkan akan semakin meningkat. Kuat lekat beton serat tertinggi divariasi penggunan AAT $0 \%$ dan penambahan serat bambu $3 \%$.

2. Peggunaan AAT dan penambahan serat bambu tidak berpengaruh terhadap porositas beton serat. Penggunaan AAT berpengaruh negatif terhadap porositas beton serat. Penambahan serat bambu berpengaruh negatif terhadap porositas beton serat. Porositas beton serat semakin meningkat hingga penambahan serat bambu $3 \%$ dan setiap penggunaan AAT $5 \%-15 \%$ menyebabkan porositas semakin meningkat

3. Nilai optimal penggunaan AAT dan penambahan serat bambu yang menghasilkan kuat lekat maksimal sebesar 63,04 MPa pada persentase penggunaan AAT 0\% dan penambahan serat bambu 3\%.

4. Nilai optimal penggunaan AAT dan penambahan serat bambu yang menghasilkan porositas minimal sebesar $14,21 \%$ pada persentasi penggunaan AAT 0\% dan penambahan serat bambu 3\%.

\section{B. Implikasi}

Penelitian ini menunjukan bahwa penggunaan AAT dan penambahan serat bambu pada beton serat berpengaruh terhadap kuat lekat. Persentase penggunaan AAT paling baik adalah $5 \%$ dan persentase penambahan serat bambu paling baik adalah 3\%. Hasil penelitian ini memberikan beberapa implikasi, antara lain:

1. Dalam bidang teknologi beton, penelitian ini memberikan informasi mengenai persentase penggunaan AAT dan penambahan serat bambu sebagai alternatif perbaikan mutu, disamping itu memanfaatkan limbah dari pabrik pengolahan tebu.

2. Dalam bidang ilmu pendidikan, penelitian ini dapat dijadikan refrensi bahan ajar untuk mata kuliah yang berhubungan 
dengan teknologi pengembangan beton.

\section{Saran}

Berdasarkan simpulan dan implikasi hasil penelitian pembahasan tentang penggunaan AAT dan penambahan serat bambu sebagai bahan tambah beton serat terhadap kuat lekaat, dan porositas, maka dapat dikemukakan saran-saran sebagai berikut:

1. Perlu adanya pengembangan penelitian lebih lanjut untuk pemanfaatan limbah abu ampas tebu sebagai bahan pengganti agregat halus pada beton dan penambahan serat bambu dengan variasi yang berbeda dari penelitian ini untuk mendapatkan nilai kuat lekat dan porositas yang lebih baik dari penelitian ini.

2. Perlu adanya pengembangan penelitian lebih lanjut mengenai cara pembuatan beton serat bambu sebagai bahan tambah dan AAT sebagai bahan pengganti agregat halus.

3. Perlu adanya pengembangan penelitian lebih lanjut mengenai beton serat dengan bahan tambah yang lain.

4. Perlu adanya pengembangan penelitian lebih lanjut untuk metode penggunaan AAT dan penambahan serat bambu pada beton serat sehingga dihasilkan kuat lekat maksimal dan porositas minimal yang lebih baik dari penelitian ini.

\section{DAFTAR PUSTAKA}

,(1989) Standar Nasional Indonesia $S$ 04-1989-F
Pemakaian Air Untuk

Beton. Badan

Standarisasi Nasional

,(1990). Standar Nasional Indonesia 03-1968-1990. Metode Pengujian Tentang Analisis Saringan Agregat Halus Dan Kasar. Badan Standarisasi Nasional

,(2000). Standar Nasional Indonesia 03-2834-2000. Tata Cara Pembuatan Rencana Campuran Beton Normal. Badan Standarisasi Nasional

,(2004). Standar Nasional Indonesia 15-2049-2004. Semen Portland. Badan Standarisasi Nasional

,(2008). Standar Nasional Indonesia 03-1972-2008. Pelaksanaan Uji Slump. Badan Standarisasi Nasional

,(2008). Standar Nasional Indonesia 1970:2008. Cara Uji Berat Jenis dan Penyerapan Air Agregat Halus. Badan

Standarisasi Nasional

(2008). Standar Nasional Indonesia 2417:2008. Cara Uji Keausan Agregat Dengan Mesin Abrasi Los Angeles. Badan Standarisasi Nasional 
,(2011). Standar Nasional Indonesia 2493:2011. Tata Cara Pembuatan Dan Perawatan Benda Uji Beton Di Laboratorium. Badan Standarisasi Nasional

Dikutip:

http://junaidichaniago.wo rdpress.com (Senin, 6 Februari 2017 jam 20.15)

Junaidi. (2010). Titik Persentase Distribusi F Probabilita=0.05.

,(2013). Standar Nasional Indonesia 2847:2013. Persyaratan beton Struktural untuk bangunan gedung. Badan Standarisasi Nasional

(1990). Standar Nasional Indonesia 03-1970-1990 Metode Pengujian Kadar Air. Badan Standarisasi Nasional

.(2000). ASTM C 642: Standard Test Method for Density, Absorption, and Voids in Hardened Concrete.

.(2007). ASTM C150-07: Standard Specification for Portland Cement: american society for testing and materials

.(2008). Standar Nasional Indonesia 1969:2008 Berat Jenis Agregat Kasar. Badan Standarisasi Nasional

Antoni, dkk. (2008). Teknologi Beton. Yogyakarta : Andi

Asroni, Ali. (2010). Balok dan Pelat Beton Bertulang. Yogyakarta : Graha Ilmu

Linna. (2005). Pengujian Kuat Tekan Beton Dengan Tambahan Abu Ampas Tebu Dan Gips, Skripsi, Jurusan Teknik Sipil, Fakultas Teknik, Universitas Atma Jaya Yogyakarta

Morisco. (1996). Bambu sebagai Bahan Rekayasa, Pidato Pengukuhan Jabatan Lektor Kepala Madya Fakultas Teknik UGM, Yogyakarta

Morisco. (1999). Rekayasa Bambu, Nafiri Offset, Yogyakarta

Mulyono, Tri. (2004). Teknologi Beton. Yogyakarta : Andi

Olanda, Suci. (2013). Pengaruh Penambahan Serat Pinang (Areca Catechu L. Fiber) Terhadap Sifat Mekanik Dan Sifat Fisis Bahan Campuran Semen Gipsum. Skripsi. Jurusan Fisika FMIPA. Universitas Andalas

Pangestuti, E, Kanti. (2014). Pengaruh Penambahan Limbah Pembakaran Ampas Tebu Pada Paving Terhadap Jenis Semen PPC Dan PCC. 
Skripsi. Jurusan Fakultas

Teknik, Universitas

Negeri Semarang

(UNNES).

Rompas, G.P., dkk. (2013).

Pengaruh Pemanfaatan

Abu Ampas Tebu Sebagai

Substitusi Parsial Semen

Dalam Campuran Beton

Ditinjau Terhadap Kuat

Tarik Lentur Dan

Modulus Elastisitas,

Jurnal Sipil Statik Vol.1

No.2 82-89

Sihotang, Emelda. (2009). Pemanfaatan Abu Ampas Tebu Pada Pembuatan Mortar. Skripsi. Jurusan MIPA. Universitas Sumatera utara

Soroushian,P, Bayasi,Z. (1987). Mechanical properties of Fiber Reinforced Concrete, Procceding of the International Seminar on Fiber Reinforced Concrete, Michigan State University, Michigan, USA

Subramani, T. (2015). Experimental Study On Bagasse Ash In Concrete, Vinayaka Missions University, Salem, India

Sugiyono. (2010). Statistika Untuk Penelitian. Bandung: Alfabeta

Suhardiman, Mudji. (2015). Kajian Pengaruh Penambahan
Serat Bambu Ori

Terhadap Kuat Tekan Dan Kuat Tarik Beton. Jurnal Penelitian, Universitas Janabadra. Diperoleh Pada 8 oktober 2016

Tjokrodimuljo, K. (1992). Bahan Bangunan, Jurusan Teknik Sipil, Fakultas Teknik, Yogyakarta: Universitas Gadjah Mada.

Tjokrodimuljo, Kardiyono. (2004). Teknologi Beton. Yogyakarta : Universitas Gajah Mada 